\title{
PERTURBAREA AUZULUI - COMPONENTĂ A SINDROMULUI ALCOOL FETAL
}

\author{
Georgiana Russu', Cristina Rusu ${ }^{2}$, Alexandra Grosu ${ }^{3}$ \\ ${ }^{1}$ Clinica de Cardiologie Pediatrică, \\ Spitalul Clinic de Urgență pentru Copii „,Sf. Maria“, Iaşi \\ ${ }^{2}$ Catedra de Genetică Medicală, \\ Universitatea de Medicină şi Farmacie „, Gr. T. Popa “, Iaşi \\ ${ }^{3}$ Spitalul Clinic de Urgență pentru Copii ,,Sf. Maria “, Iaşi
}

\begin{abstract}
REZUMAT
Sindromul alcool fetal (SAF) (1-2/1.000 nou-născuți viabili), consecință a ingestiei precoce de alcool în timpul gravidității, asociază: deficiența persistentă a creşterii taliei, greutății şi circumferinței craniene, anomalii faciale caracteristice, malformații cardiace (predomină defectele septale), anomalii minore ale articulațiilor şi extremităților, deficiențe ale dezvoltării şi funcției sistemului nervos central. Complexitatea, gravitatea şi frecvența modificărilor este variabilă în funcție de consumul de alcool asociat sau nu altor riscuri: status socioeconomic scăzut, perturbări psihologice, fumat, droguri. Afectarea auzului sub efectul alcoolului, neinclusă clasic în sindromul alcool fetal precum şi infecțiile cronice ale urechii se asociază cu grade variabile de severitate. Examinările de specialitate aplicate sistematic la copiii cu SAF mai mult sau mai puțin sever au dus la conturarea a patru tipuri principale de perturbări ale auzului: întârzierea dezvoltării funcției auditive asociată cu perturbări ale vorbirii, pierderea neuro-senzorială a auzului (afectarea urechii medii şi a căilor auditive), pierderi intermitente ale funcției de conducere a vibrațiilor sunetului, pierderea auzului prin leziuni centrale. Identificarea precoce a anomaliilor de auz, de origine conductivă sau neuro-senzorială, contribuie la ameliorarea prognosticului prin intervenții recuperatorii precoce.
\end{abstract}

Cuvinte cheie: alcool, sarcină, hipoacuzie

Efectele teratogene ale consumului de alcool în timpul sarcinii au fost descrise pentru prima data în literatura medicală în urmă cu aproape 5 decade (1). Jones şi Smith, în 1973, au reunit anomaliile dezvoltării somatice şi neuro-senzoriale ale copiilor din mame alcoolice sub denumirea de sindrom alcool fetal (SAF) (2).

Incidența SAF variază în funcție de populaţia studiată, de criteriile folosite şi de metoda de evaluare. Astfel, în SUA frecvența este estimată la 1-2 din 1.000 nou-născuți, în timp ce în zonele cu risc înalt, cum ar fi unele comunități din Africa de Sud, studiul populației pediatrice a demonstrat o frecvență de 4-5\% în rândul copiilor din clasele primare (3).

Deşi consumul matern de alcool este determinantul principal al efectelor negative asupra fătului, s-a demonstrat că şi expunerea paternă la alcool poate induce malformații asupra fătului. Manifestările clinice cel mai frecvent întâlnite sunt: dismorfie facială (microcefalie, microftalmie, fante palpe- brale scurte, epicantus, hipoplazie maxilară cu aspect de facies aplatizat, filtru nazal hipoplazic, buza superioară subțire, micrognație, cleft al palatului osos), retard al creşterii intrauterine sau postnatal, retard mintal şi tulburări de comportament. Alte consecințe ale consumului de alcool în timpul sarcinii sunt: avort spontan, naştere prematură, deces intrauterin, afectarea dezvoltării scheletului, sindrom de sevraj al nou-născutului.

Modificările expresiei genelor (procese celulare normale în genom) fără afectarea secvențialităţii ADN sunt cunoscute ca procese epigenetice. Alcoolul perturbă procesul normal al diferențierilor celulare modificând expresii ale genelor specifice de țesut. Acționează la nivelul componentelor nucleosomului dereglând metilarea ADN, acetilarea histonelor şi interacţiunilor microARN. Astfel, alcoolul se înscrie pe lista factorilor majori de risc pentru resetări epigenetice soldate cu anomalii multiorganice (4).

O meta-analiza efectuată pe 20 de studii publicate între 1987 şi 2013 (5) a relevat faptul că mal-

Adresa de corespondență:

Georgiana Russu, Spitalul Clinic de Urgență pentru Copii „Sf. Maria“, Strada Vasile Lupu nr. 62, Iaşi

E-mail: g_russu@yahoo.com 
formațiile cardiace apar la $67 \%$ dintre copiii mamelor care au consumat alcool în timpul sarcinii, fiind reprezentate de defecte septale atriale sau ventriculare $-21 \%$, tetralogie Fallot şi defecte cono-truncale $6 \%$ şi alte tipuri de malformații (6). Efectul teratogen al alcoolului depinde de momentul consumului, frecvența, durata şi cantitatea de alcool consumată, dar şi de absorbția şi metabolizarea alcoolului de către mamă şi făt, proces cu determinare genetică (7).

Malformațiile cranio-faciale sunt datorate alcoolului consumat în perioada organogenezei (ziua 18-40 de sarcină), în timp ce modificările sistemului nervos apar mai târziu pe parcursul sarcinii. Postnatal, pe măsură ce copilul creşte, se remarcă tot mai mult deficitele cognitive ce pot merge până la retard mental sever, precum şi alte tulburări de ordin psihic cum este, spre exemplu, deficitul de atenție, impulsivitate, probleme de memorie. Frecvent se asociază tulburări de limbaj, coordonare dificilă a mişcărilor fine, tulburări de comportament, tonus muscular scăzut, diverse probleme psihiatrice. De altfel, consumul prenatal de alcool reprezintă principala cauză nonereditară de retard mintal (8).

A fost avansată ipoteza conform căreia alcoolul împiedică transferul aminoacizilor esenţiali şi a zincului de la mamă către făt, consecința fiind dificultatea sintezei proteinelor şi, prin urmare, handicapul creşterii şi dezvoltării fetale (9). Confirmarea consumului de alcool în timpul sarcinii folosind biomarkerii cunoscuți în practica curentă rămâne o provocare. Recent a fost propusă includerea microARN în profilul investigațiilor SAF.

Moleculele microARN au rol critic în procese biologice importante, în special in utero, care asigură dezvoltarea normală prin echilibrarea balanței între supraviețuirea celulelor şi proliferarea lor. În condiții experimentale s-a demonstrat că expunerea la etanol supresează gene implicate în reglarea organogenezei, în diverse etape ale dezvoltării embrionului şi fătului. Au fost identificate patru tipuri de microARN supresate de etanol în celulele stem neurale (4).

Gardiner şi colab. au observat că modificarea nivelului circulant al microARN din serul matern se asociază cu variate stadii de boală descrise în cadrul spectrului de anomalii din SAF şi au publicat datele obținute în aprilie 2016, acesta fiind primul raport care demonstrează utilitatea folosirii microARN ca biomarker al expunerii la alcool (10).

În ultimele două decenii au apărut lucrări privind modificările structurale ale creierului determinate de alcool, soldate cu deficite cognitive şi modificări de comportament, atât la copiii cu dismorfie caracteristică SAF, cât mai ales la cei fără microcefalie (11).

A fost semnalată asocierea SAF cu afectarea auzului; originea embriologică comună a structurilor cranio-faciale şi oculare cu cele ce vor constitui aparatul auditiv, favorizează asocierea SAF cu afectarea auzului. Aceste structuri provin din primele două arcuri brahiale şi au perioade similare de sensibilitate la expunerea la substanțe toxice. Drept urmare, apare întârziere în maturarea componentelor auditive, deficiență neuro-senzorială auditivă, deficit central. La aceste modificări se asociază intermitent deficiența de tip mecanic, consecință a otitelor medii seroase la care sunt predispuşi aceşti copii. Afectarea vestibulară, relativ frecventă, favorizată de originea embriologică comună, poate rămâne la nivel subclinic. Deficiența auditivă asociată celei cognitive conlucrează, determinând un cerc vicios care are drept urmare întârziere în dezvoltarea limbajului, defecte de limbaj şi accentuarea deficitului cognitiv prin stimulare insuficientă $(12,13)$.

Datele acumulate în ultimul deceniu au permis conturarea a patru mecanisme ce se interconectează şi determină deficiența de auz:

- întârzierea în maturarea structurilor destinate auzului;

- afectare auditivă neuro-senzorială;

- reducerea intermitentă a funcției de conducere a sunetului care apare odată cu fiecare nou episod de otită medie seroasă;

- afectare auditivă de tip central.

Latențele obținute din partea cortexului auditiv primar pot reprezenta suma latențelor la toate nivelele procesului auditiv, din momentul în care semnalul sonor traversează cohleea, de-a lungul fluxului nervos până la cortexul auditiv. De asemenea, afectarea vestibulară asociată celei auditive, induce o patologie dominată de întârzierea în achizițiile limbajului, în caracteristicile acestuia şi ca urmare accentuarea afectării cognitive (14). Church şi colab. au decelat afectare auditivă neuro-senzorială la $33 \%$ dintre copiii cu SAF comparativ cu 2-3\% în populația generală, ca şi tulburări de transmisie datorită infecțiilor otice recurente, care pot avea o frecvență de până la $92 \%$ la lotul SAF față de $<20 \%$ în populația generală (12).

RMN a pus în evidență modificări ale corpului calos (15), sugerând risc de specializare hemisferică atipică, în special în aria vorbirii, limbajului şi auzului. Perturbarea transferului interemisferic determină alterarea funcției de lateralizare, copiii cu SAF au prezentat un număr mare de erori la nivelul urechii drepte în timpul unui test de ascultare, indicând asimetrie funcțională (16). 
Studii experimentale efectuate pe şoareci expuşi antenatal la doze diferite de alcool etilic au observat că aproape toți prezentau hipoacuzie mai ales prin afectare neurosenzorială. Atât celula receptoare, cât şi calea de transmisie prezentau malformații, consecința fiind întârzierea transmisiei sunetului, o problemă de percepție a acestuia şi, pe măsură ce îmbătrâneau, cei expuşi la doze mai mari de alcool au manifestat scăderea mai rapidă a acuității auditive. Mai mult, expunerea la sunete capabile să producă traumă acustică accentuează procesul de degradare a funcției senzoriale (17).

Un studiu clinic raportează un procent semnificativ de $93 \%$ de copii cu SAF la care otita seroasă medie apare în mod recurent bilateral, 30\% dintre aceştia prezentând afectare neuro-senzorială pentru care au necesitat amplificare mecanică a sunetelor. De asemenea, malformațiile eustachiene cuplate cu deficitul de tip imun de care suferă aceşti copii îi predispune la infecții ale căilor respiratorii superioare. Posibilul efect ototoxic direct al alcoolului precum şi sindromul neuro-ectodermal determinat de acest agent teratogen explică prezența tipică a afectării auditive în cadrul SAF, deşi această componentă în mod eronat nu este încă recunoscută ca fiind unul dintre elementele caracteristice ale sin- dromului. Acceptarea acestei idei ar lărgi schema terapeutică în cazul pacienților diagnosticați şi ar putea determina îmbunătățirea prognosticului psihologic, medical şi social (13).

Aplicarea magneto-encefalografiei la copiii de vârstă preşcolară cu SAF şi audiogramă normală a decelat latența răspunsului neuro-fiziologic la stimuli auditivi. Această latență s-a dovedit a fi un marker neural eficient al dificultăţilor de procesare a informației la copiii cu SAF. De aceea, autorii propun includerea acestei testări în algoritmul de diagnostic al SAF în special la copiii fără dismorfie evidentă (18).

\section{CONCLUZII}

SAF, a cărui gravitate depinde de precocitatea şi abundența consumului de alcool, asociază frecvent deficiențe de auz. Toxicitatea alcoolului întârzie maturarea structurilor destinate auzului, afectează componenta auditivă neuro-senzorială şi de tip central, creează probleme în conducerea sunetului. Hipoacuzia, inclusă ca element de diagnostic al SAF, trebuie depistată precoce, tratată adecvat, pentru o bună dezvoltare a limbajului, ameliorarea calității vieții şi o mai bună integrare psiho-socială. 